\title{
Assessment of the Hydraulic Performance of the Drainage System in Dire Dawa Town
}

\author{
Moges Tariku \\ College of engineering and technology, Wolkite University, PO box 07, Wolkite, Ethiopia
}

\begin{abstract}
The constructed drainage structure was expected to carry the design discharge which generated from the catchment area and dispose safely to the outlet points. The study has mainly focused to assessing current status of drainage system and evaluates the hydraulic performance of the drainage system. The rational methods have been used to calculate proposed discharge and HY-8 software used for culvert analysis. The current drainage status of the towns was poor, the road performance was reduced to deliver, the service life of the road reduced, and the cost for maintaining the road increased, the compression between the proposed and existed carrying capacity of drainage structures showed that the exist drainage structures are hydraulically insufficient. HY 8 result shows the existed culvert was hydraulically insufficient and $50-63.5 \%$ of the proposed peak discharge overtopped and flows on the road.
\end{abstract}

Keywords: Poor drainage, Road performance, Hydraulic Performance

DOI: $10.7176 / C E R / 12-11-01$

Publication date: November $30^{\text {th }} 2020$

\section{Introduction}

According to [1], infrastructure development in Africa is abysmal, lagging behind the rest of the world in terms of quality, quantity, and access. The situation is worse in poor countries like Ethiopia, where a myriad of problems have made the supply of physical infrastructure and services to continually lag behind the urban population growth rate.

Urban storm water drainage facilities are part of the urban infrastructure elements and the design of these facilities requires due attention. In Ethiopia context, where watershed of many urban centers receive a significant amount of annual rainfall and where rainfall intensity is generally high, control of runoff at the source, flood protection, and safe disposal of excess water/runoff through proper drainage facilities becomes essential[2,6].

Due to the development of infrastructures as a result of urbanization, the surface runoff water greatly increased in the town damaging the roads. They contributed runoff water thus needs to be safely disposed to the rivers/outlet channels so that the functional utility of the road infrastructure maintained and thereby avoid the damages which occurred to the road and property $[3,7$ and 6$]$.

Adequate drainage is very essential in the design of highways since it affects the highway's serviceability and usable life. If ponding on the traveled way occurs, hydroplaning becomes an important safety concern. Drainage design involves providing facilities that collect, transport and remove storm water from the highway|3,6 and 7].

The pattern of urbanization and modernization in Ethiopia has meant to increase densification along with urban infrastructure development. This has led to deforestation, the use of corrugated roofs and paved surfaces. The combined effect of this results in higher rainfall intensity and consequently accelerated and concentrated runoff in the urban areas. Due to inadequate integration between the road and urban storm water drainage infrastructure provision, many areas are exposed to flooding problems and road damages in urban roads 44 and 9$\rfloor$.

Dire Dawa is one of the largest city in Ethiopia and which frequently attacked by flood hazards. Since Dire Dawa lying at the foot of the mountain range, it is subjected to annually flooding by runoff from the mountain during torrential rains and it still occurs when there are heavy rainfalls in the surrounding high land areas of Haramaya, Kersa, Dengego, and Qulubi. So this makes the drainage problems of the town becomes the more serious and main concern $\lfloor 5,10]$.

The roads at station S.CM 5, station 1+600.311 has been eroded and formed gullies due to the absence of side ditches the runoff directly flows over the road and distracts the road service to the community and requires high investment cost for maintenances.

The culverts at station S.CM-6, 2+190.36 and at station S.CM_8, 2+060.943 has been filled with sediments and debris from the nearby community, some communities use the culverts as a means of solid waste disposal areas and blocked the culverts working spaces.

The thesis gives high emphasize to assess the hydraulic performance of the drainage system in Dire Dawa town and specifically assess the current conditions of drainage system and evaluate the hydraulic performance of the drainage system.

The research is beneficial to the drainage and roads sectors of different urban areas for future road drainage system construction. This research was also useful for those involved in academicians and researchers who conduct similar researches on the other road drainage system, erosion and scouring prevention mechanisms and degradation 
of the stream channel.

This thesis is limited to the assessment of the hydraulic performance of the drainage system in Dire Dawa Town and recommending some way of reducing or minimizing the problems which are found in this research assessment regarding the drainage system. This research gives high emphasis on water-related problems which lead to poor drainage. The work does not cover the structural analysis rather it simply identifies the shapes, size, and type of drainage required.

\section{Research Methodology}

The researcher uses both exploratory and descriptive way of expressions to reach a reasonable conclusion and achieving the research objectives.

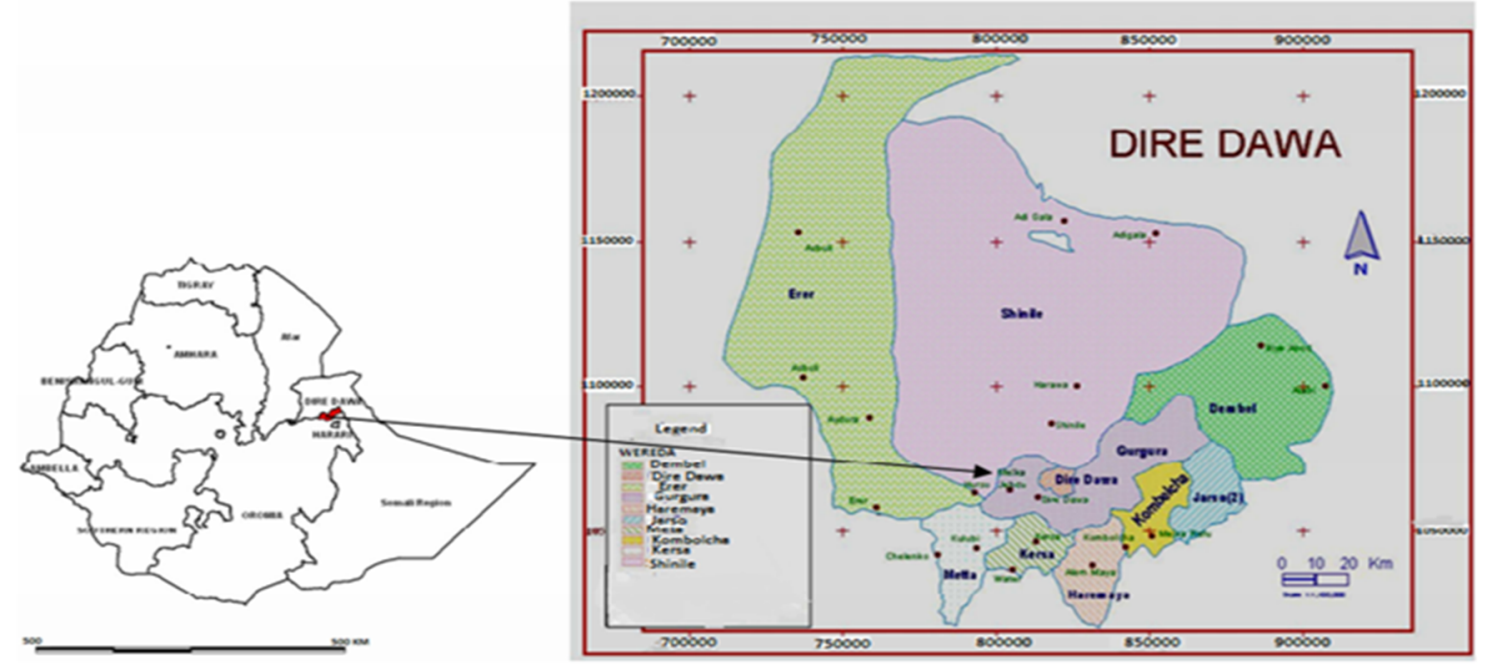

Figure 1: Location map of the study area

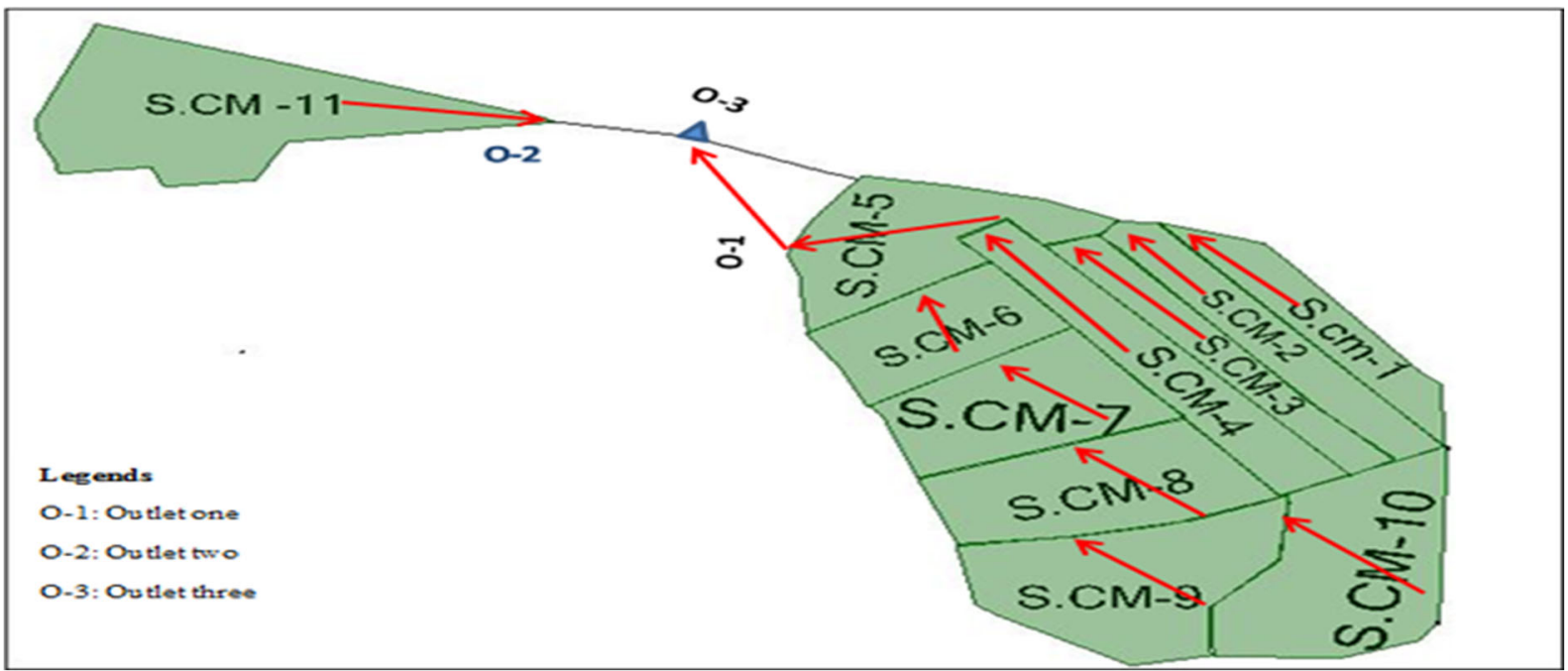

Figure 2: The sub-catchment areas of the study area

\subsection{Data sources}

The researcher uses both primary and secondary data types. Under primary data sources the existed cross sectional area, width, elevations, side slope, bed slope, inlet and out let elevations, and roughness coefficient of different types of drainage systems in the town.

Under secondary data sources these researcher collects different data. From different organizations like, Metrological data, drainage master plan of the town, the land use land cover coverage's of the town, and different published and unpublished documents about drainages.

\subsection{Data collection methods}

For this study basically the following data collection methods have been employed:

1. Personal observations of the study area to assess the current status of the drainage system of the towns and to 
show the true state of the drainage system and the roads performance and Field survey of different site and collect the cross section, depths, widths slopes, elevations, etc to evaluate the hydraulic performance of the drainage system of the towns.

2. Direct interviews with the administrative body of the town sewerage and drainage system to answer the drainage coverage of the tows and to know the root cause for the occurrence of poor drainage in the towns.

\subsection{Data analysis}

The collected data were analyzed by using Microsoft Excel, Global Mapper, ARC-GIS 10.4, and HY-8 culvert analysis software.

The ARC-GIS 10.4 and Global mapper program was used for the preparations of the study areas of sub-catchment areas, location map preparations of the study area, and land use land cover preparations.

HY-8 program was used for the analysis of the existed culvert performance by iterating different discharge and shows how much of the water overtops from the culvert and directly flows on the road.

Microsoft Excel program was used for the computations of proposed maximum discharges from each sub catchment areas by the rational formulae and different interviewed results has been analyzed by the excel sheets by simple mathematics.

Data presentation

Once the data has been analyzed the next step was presenting the data in a clear and concise manner, for that sick of matter the researcher uses figures which have been done by the global mapper and ARC-GIS 10.4 and Microsoft Excel, tables, photographs, and percentages.

\section{Result and Discussion}

\subsection{The current condition of drainage system in the town}

The current road coverage of the towns was $14.36 \%$ of the total area of the town $\left(124.34 \mathrm{~km}^{2}\right)$ and most of the roads have been faced problems from the drainage system. Most of the problems which have been directly associated with the poor drainage system of the towns.

From the response of the engineers from drainage and road authority they have been formalized in the following points. The poor drainage affects the road performance every year by overspreading the floods on the road and creates inundation of the road and the nearby houses.

The poor drainage affects the road performance every year by overspreading the floods on the road and creates inundation of the road and the nearby houses.

For each rainy season the administrative body invests much money for maintenance and cleaning of ditches, but still the drainage problem reduced the service life of the road.

The impact of poor drainage condition on road pavement is very adverse. It causes pavement distresses and deterioration which affect the safety and riding quality on the pavement. The study investigated cases of pavement failures and damages due to poor drainage experienced during the rainy season

Generally the effects of poor drainage system on the roads have been listed bellows:

$\checkmark$ Reducing the load carrying ability of the subgrade, sub base, asphalts and shoulder of the road.

$\checkmark$ Eroding the road side surface by washing away the top surface of the road.

$\checkmark \quad$ Runoff the road and block a road by deposited waste material on the road and water leaved debris on the road and thaw weakening and stripping the asphalt in asphalt pavement road.

The results from personal observation of the site have been figure out in pictures which existed in the figure (fig. 1 -fig.4) part bellows, and that shows the destruction of traffic flow by flooding the road, side deterioration and formation of gullies on the road sides, culverts has been filled with debris and flood overtopped on the roads etc. 


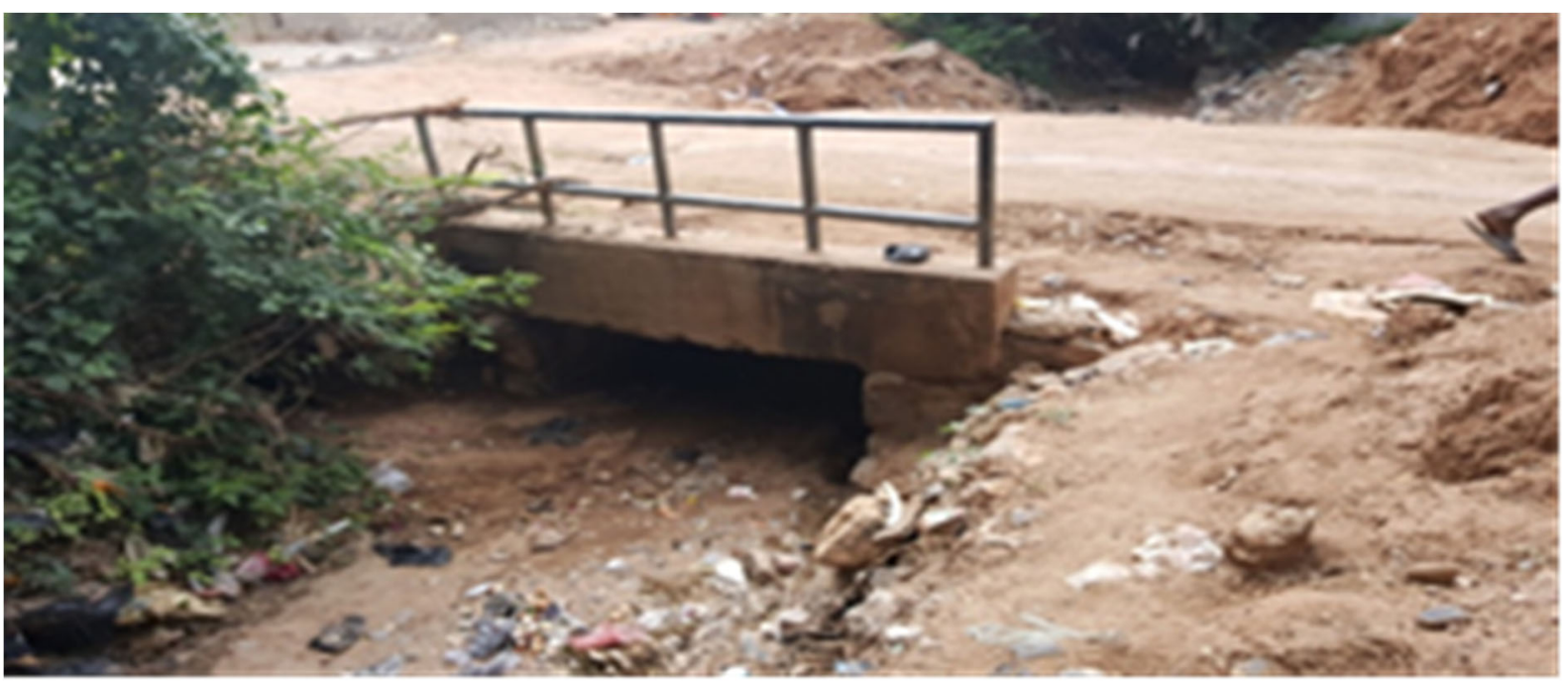

Figure 3: Almost all filled with the sedimentation of side ditches

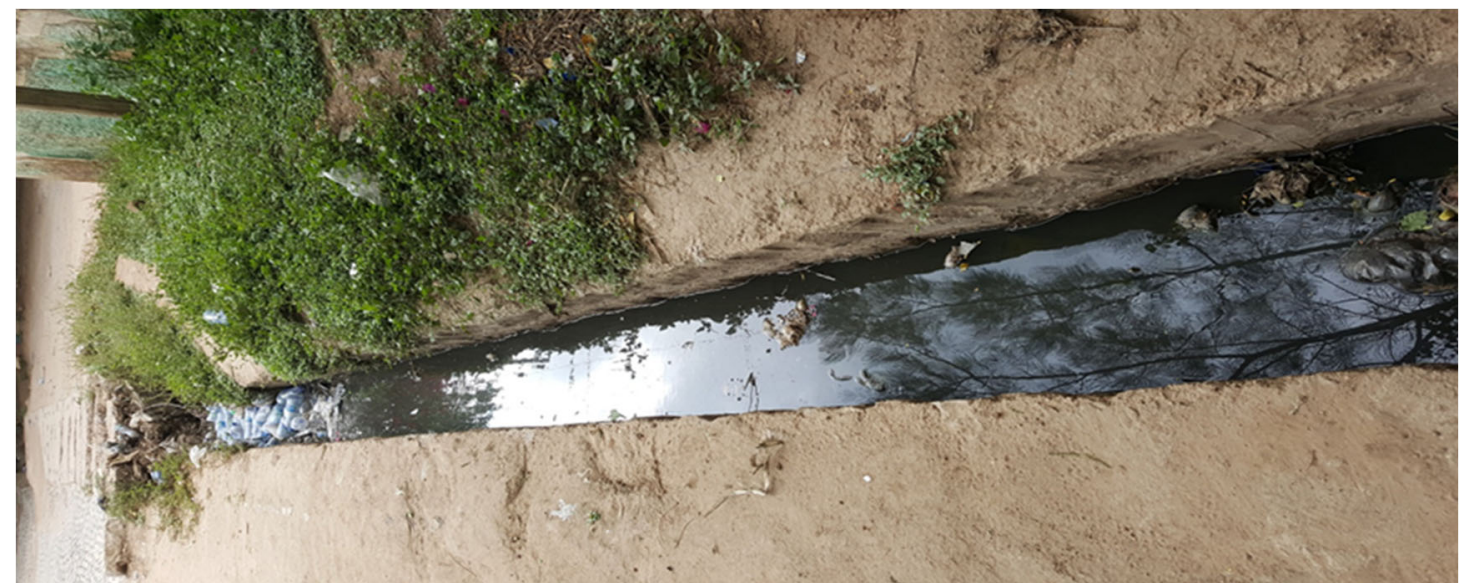

Figure 4: Solid waste and dust accumulation in the drainage system and creates water stagnation in the side channel

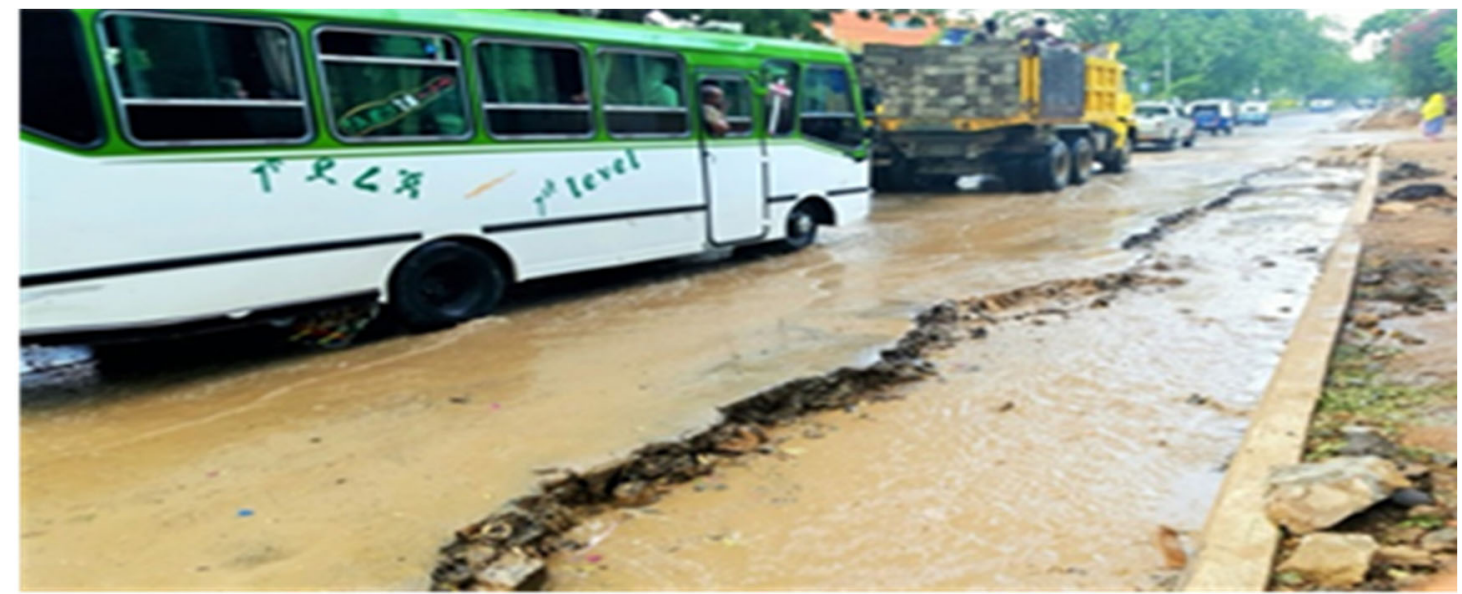

Figure 5: Flooding to both the right and left side of the drainage system 


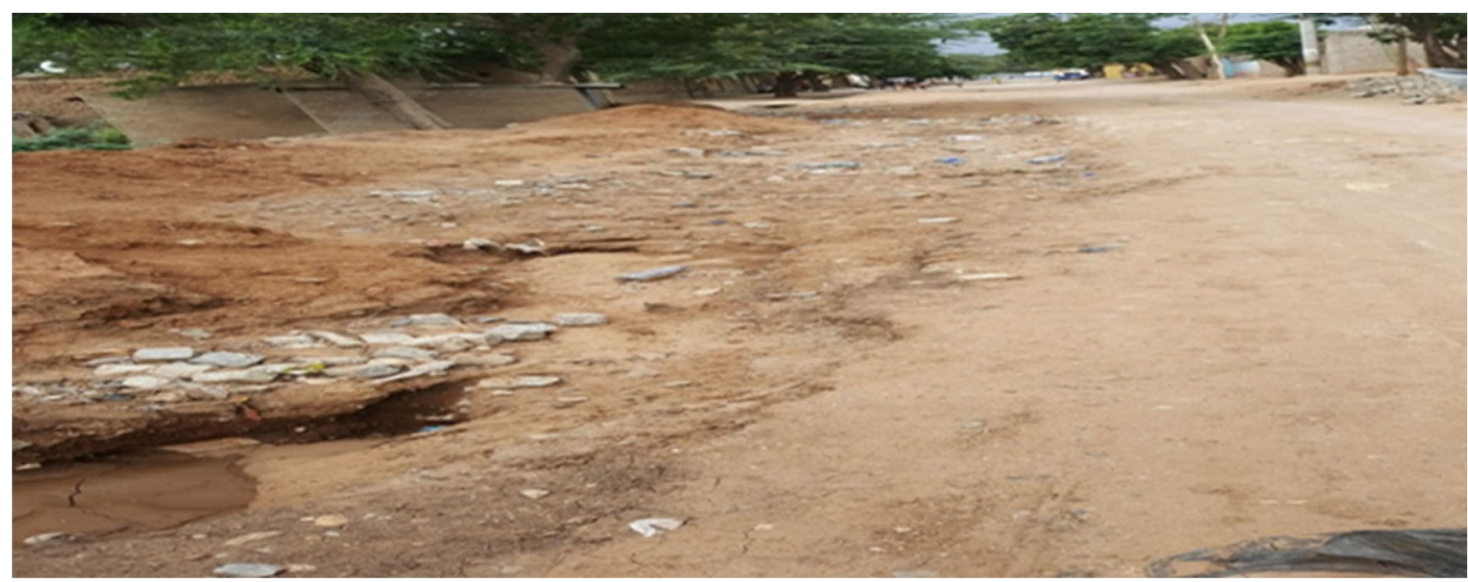

Figure 6: Eroded roads and gully formations due to lack of side ditches

\subsection{Evaluating Hydraulic Performance of the Drainage System}

\section{A. Comparison of proposed Peak design discharge and existed drainage structure capacity}

From the table 1 which show that the proposed maximum discharge computations which indicated that column number 1 shows the sub-catchment name in the study area, the column number 2 shows that the area coverage of each sub-catchments measured by hectares, the column number 3 shows the weighted runoff coefficients of each sub-catchments, the column number 4 indicates that time of concentration from each sub-catchments, the column number 5 indicates that for each sub-catchments the intensity from ERA IDF curve measured by $\mathrm{mm} / \mathrm{hr}$ for different return periods, and column number 6 indicates the computed proposed maximum discharge by rational methods $(\mathrm{Q}=0.00278 \mathrm{CIA})$.

From table 2 which show the existed working spaces of different types of drainage structures in different subcatchments of the study area measured using tap meters and also observing the roughness coefficients, and side and bed sloped of each drainage structures. Finally the computations of the carrying capacity of the drainage structures have been shown by manning formulae.

Table 1: Proposed Maximum Discharge Computation by the rational formulae for the study area

\begin{tabular}{|c|c|c|c|c|c|c|c|c|c|}
\hline \multirow{3}{*}{ Catch. ID } & $\operatorname{Col}(2)$ & $\operatorname{Col}(3)$ & $\operatorname{Col}(4)$ & $\operatorname{Col}(5$ & & & $\operatorname{Col}(6$ & & \\
\hline & \multirow[t]{2}{*}{$\operatorname{Area}(\mathrm{Ha})$} & \multirow[t]{2}{*}{$\mathrm{C}$} & \multirow[t]{2}{*}{$\operatorname{Tc}(\min )$} & \multicolumn{3}{|c|}{ Intensity $(\mathrm{mm} / \mathrm{hr}$.) for different Return Period } & \multicolumn{3}{|c|}{$\begin{array}{l}\text { Proposed discharge } \\
(\mathrm{Q}=0.00278 \text { CfCIA) }\end{array}$} \\
\hline & & & & $5 \mathrm{YR}$ & $10 \mathrm{YR}$ & $25 \mathrm{YR}$ & Q5 & Q10 & Q25 \\
\hline S. CM 1 & 5.75 & 0.57469 & 12 & 94 & 107 & 120 & 0.865 & 0.982 & 1.21369 \\
\hline S. CM2 & 6.42 & 0.52974 & 21 & 79 & 90 & 100 & 0.745 & 0.847 & 1.04218 \\
\hline S. CM 3 & 5.45 & 0.54898 & 19 & 82 & 93 & 104 & 0.679 & 0.773 & 0.9513 \\
\hline S. CM 4 & 9.75 & 0.55 & 16 & 88 & 98 & 110 & 1.312 & 1.461 & 1.80384 \\
\hline S. CM 5 & 4.19 & 0.51885 & 26 & 67 & 77 & 86 & 0.405 & 0.465 & 0.57173 \\
\hline S. CM 6 & 13.19 & 0.44421 & 12 & 94 & 107 & 120 & 1.538 & 1.745 & 2.15803 \\
\hline S. CM 7 & 14.49 & 0.48333 & 12 & 95 & 107 & 121 & 1.841 & 2.089 & 2.58351 \\
\hline S. CM 8 & 23.53 & 0.475 & 10 & 99 & 112 & 126 & 3.063 & 3.473 & 4.2996 \\
\hline S. CM 9 & 14.59 & 0.485 & 10 & 98 & 111 & 125 & 1.92 & 2.177 & 2.69477 \\
\hline S. CM 10 & 16.38 & 0.56145 & 13 & 92 & 105 & 119 & 2.352 & 2.684 & 3.34662 \\
\hline S. CM 11 & 20.04 & 0.49568 & 19 & 82 & 93 & 104 & 2.254 & 2.562 & 3.15508 \\
\hline
\end{tabular}

Table 2: Existed drainage channels and their hydraulic carrying capacity

\begin{tabular}{|l|l|l|l|l|}
\hline Catchments Name & S.C.M 1 & S. C.M 5 & S. C.M 4 & S. C.M 11 \\
\hline Drainage Type By Shape & Rectangular & Curricular Pipe & Rectangular & Rectangular \\
\hline Cross Section Data (W, Y) & $\begin{array}{l}\mathrm{W}=45 \mathrm{~cm}, \\
\text { Y=30 Cm }\end{array}$ & $90 \mathrm{~cm}$ & W=45cm, Y=25cm & W=45cm, Y=45cm \\
\hline Area $\left(\mathrm{m}^{2}\right)$ & 0.135 & 0.63585 & 0.1125 & 0.2025 \\
\hline Perimeter(m) & 1.05 & 2.826 & 0.95 & 1.35 \\
\hline Hydraulic Radius R(m) & 0.128571428 & 0.225 & 0.118421053 & 0.15 \\
\hline Slope & 0.03 & 0.026 & 0.03207331 & 0.012658 \\
\hline Roughness Coefficient & 0.02 & 0.014 & 0.02 & 0.013 \\
\hline Side Slope & $1 \mathrm{~V}: 1 \mathrm{~h}$ & & $1 \mathrm{v}: 1 \mathrm{~h}$ & $1 \mathrm{v}: 1 \mathrm{~h}$ \\
\hline Calculated Discharge $\left(\mathrm{m}^{3} / \mathrm{s}\right)$ & $\mathbf{0 . 2 9 7 8 2 4 7}$ & $\mathbf{2 . 7 0 9 1 6 2 1 0 8}$ & $\mathbf{0 . 2 4 2 9 2 9 5 6 1}$ & $\mathbf{0 . 4 9 4 7 5 6 7 4 9}$ \\
\hline
\end{tabular}

From the computed proposed peak discharge which stated in table 1 and the existed carrying capacity of 
drainage structures show in the table 2, the existed drainage structures are fully hydraulically insufficient and most of the drainage structures need rehabilitations and additional drainage structures installations.

From table 3 which has shown below puts clearly the comparison between the existed drainage structures and the proposed maximum design discharge on each sub-catchment. From the table 3 column 1 indicates that the subcatchments name in the study area, the column number 2 indicates that the total discharge in each sub-catchment measured by $\mathrm{m}^{3} / \mathrm{s}$, column number 3 indicates that existed drainage structures and their carrying capacity measured by $\mathrm{m}^{3} / \mathrm{s}$, column number 4 indicates that the propped maximum design discharge for both the design and check periods measured by $\mathrm{m}^{3} / \mathrm{s}$ and finally column number 5 indicates the amount of flood which overtops from the existed drainage structures(col(4) for both design and check - col(3)) measured by $\mathrm{m}^{3} / \mathrm{s}$.

Table 3: Comparison of proposed Peak design discharge and existed drainage structure capacity

\begin{tabular}{|c|c|c|c|c|c|c|}
\hline \multirow{3}{*}{$\begin{array}{l}\text { Catchment } \\
\text { identification }\end{array}$} & $\operatorname{Col}(2)$ & $\operatorname{Col}(3)$ & $\operatorname{Col}(4)$ & & $\operatorname{Col}(5)$ & \\
\hline & \multirow{2}{*}{$\begin{array}{l}\text { Total } \\
\left(\mathrm{m}^{3} / \mathrm{s}\right)\end{array}$} & \multirow[t]{2}{*}{$\begin{array}{l}\text { Existed } \\
\text { structure } \\
\left(\mathrm{Q}, \mathrm{m}^{3} / \mathrm{s}\right)\end{array}$} & \multicolumn{2}{|c|}{$\begin{array}{l}\text { Proposed Design discharge (Q, } \\
\left.\mathrm{m}^{3} / \mathrm{s}\right)\end{array}$} & \multicolumn{2}{|c|}{$\begin{array}{l}\text { Difference } \\
\text { Discharge } \\
\left(\mathrm{Q}, \mathrm{m}^{3} / \mathrm{s}\right)\end{array}$} \\
\hline & & & $\begin{array}{l}\text { Q. Design } \\
\text { (10 Yr.) }\end{array}$ & $\begin{array}{l}\text { Q. Check } \\
(25 \mathrm{yr})\end{array}$ & $\begin{array}{l}\text { Q. } \\
\text { Design } \\
\text { (10 Yr.) }\end{array}$ & $\begin{array}{l}\text { Q. } \\
\text { Check } \\
(25 y r)\end{array}$ \\
\hline S. CM 1 & Q1 & 0.297825 & 0.982 & 1.21369 & 0.68418 & 0.91587 \\
\hline S. CM 4 & $\mathrm{Q} 2+\mathrm{Q} 3+\mathrm{Q} 4$ & 2.709162 & 3.081 & 3.79732 & 0.37184 & 1.08816 \\
\hline S. CM 5 & Q1+Q5 & 0.24293 & 0.465 & 0.57173 & 0.22207 & 0.3288 \\
\hline S. CM 11 & Q11 & 0.494757 & 2.562 & 3.15508 & 2.06724 & 2.66032 \\
\hline
\end{tabular}

Table 4: Percentage of the flood which overtopped and flows on the road

\begin{tabular}{|l|l|l|}
\hline \multirow{2}{*}{ Catchment ID. } & $\%$ of Flood overflow on the Road \\
\cline { 2 - 3 } & $\mathrm{Q}\left(\mathrm{m}^{3} / \mathrm{s}\right)$ Design & \multirow{2}{*}{$\mathrm{Q}\left(\mathrm{m}^{3} / \mathrm{s}\right)$ Check } \\
\hline S.CM_1 & $69.67 \%$ & $75.46 \%$ \\
\hline S.CM_4 & $12.07 \%$ & $28.66 \%$ \\
\hline S.CM_5 & $47.76 \%$ & $57.51 \%$ \\
\hline S.CM_11 & $80.69 \%$ & $84.32 \%$ \\
\hline
\end{tabular}

Based on the comparisons of the existed and proposed peak discharges at table 4 the difference at subcatchment one (S.CM_1), $69.67 \%$ for design and 75.46\% for check, sub-catchment four (S.CM_4), $12.07 \%$ for design and $28.66 \%$ for check, sub-catchment five (S.CM 5), $47.76 \%$ for design and $57.51 \%$ for check, and finally at sub-catchment elven (S.CM_11), 80.69\% for design and $84.32 \%$ for checks has been overtopped directly on the surface of the roads. The over topped discharge directly affects the roads performance and creates an environmental problem.

B. Existed culverts analysis using HY 8 Software

Table 5: Summary of flows at the crossing - Culvert one for a 25 year return period, $13.1 \mathrm{~m}^{3} / \mathrm{s}$

\begin{tabular}{|l|l|l|l|l|}
\hline Col(1) & Col $(2)$ & Col $(3)$ & Col(4) & Col(5) \\
\hline $\begin{array}{l}\text { Headwater Elevation } \\
(\mathrm{m})\end{array}$ & $\begin{array}{l}\text { Total } \\
\text { Discharge }\left(\mathrm{m}^{3} / \mathrm{s}\right)\end{array}$ & $\begin{array}{l}\text { Culvert1, Discharge } \\
\left(\mathrm{m}^{3} / \mathrm{s}\right)\end{array}$ & $\begin{array}{l}\text { Roadway } \\
\text { Discharge }\left(\mathrm{m}^{3} / \mathrm{s}\right)\end{array}$ & Iterations \\
\hline 1202.1 & 10 & 9.66 & 0.34 & 6 \\
\hline $\mathbf{1 2 0 2 . 1 3}$ & $\mathbf{1 0 . 5}$ & $\mathbf{1 0}$ & $\mathbf{0 . 4 9}$ & $\mathbf{4}$ \\
\hline 1202.15 & 11 & 10.34 & 0.66 & 3 \\
\hline 1202.18 & 11.5 & 10.66 & 0.83 & 3 \\
\hline 1202.21 & 12 & 10.98 & 1.01 & 3 \\
\hline 1202.23 & 11.29 & 1.2 & 3 \\
\hline 1202.25 & 12.5 & 11.6 & 1.4 & 3 \\
\hline 1202.26 & 13 & 12.19 & 1.44 & 3 \\
\hline 1202.3 & 13.1 & 12.48 & 1.81 & 3 \\
\hline 1202.33 & 14 & 12.76 & 2.02 & 3 \\
\hline 1202.35 & 14.5 & $\mathbf{8 . 4 1}$ & 2.24 & 3 \\
\hline $\mathbf{1 2 0 2}$ & 15 & & $\mathbf{0}$ & Overtopping \\
\hline
\end{tabular}


Table 6: Summary of flows at the crossing Culvert one for a 50 year returns periods, $18.1 \mathrm{~m}^{3} / \mathrm{s}$

\begin{tabular}{|c|c|c|c|c|}
\hline Col(1) & $\operatorname{Col}(2)$ & Col(3) & $\operatorname{Col}(4)$ & Col(5) \\
\hline $\begin{array}{l}\text { Headwater } \\
\text { Elevation(m) }\end{array}$ & $\begin{array}{l}\text { Total } \\
\text { Discharge, }\left(\mathrm{m}^{3} / \mathrm{s}\right)\end{array}$ & $\begin{array}{l}\text { Culvert } 1 \\
\text { Discharge }\left(\mathrm{m}^{3} / \mathrm{s}\right)\end{array}$ & $\begin{array}{l}\text { Roadway } \\
\text { Discharge }\left(\mathrm{m}^{3} / \mathrm{s}\right)\end{array}$ & Iterations \\
\hline 1202.1 & 10 & 9.66 & 0.34 & 6 \\
\hline 1202.13 & 10.5 & 10 & 0.49 & 4 \\
\hline 1202.15 & 11 & 10.34 & 0.66 & 3 \\
\hline 1202.18 & 11.5 & 10.66 & 0.83 & 3 \\
\hline 1202.21 & 12 & 10.98 & 1.01 & 3 \\
\hline 1202.23 & 12.5 & 11.29 & 1.2 & 3 \\
\hline 1202.25 & 13 & 11.6 & 1.4 & 3 \\
\hline 1202.26 & 13.1 & 11.66 & 1.44 & 3 \\
\hline 1202.3 & 14 & 12.19 & 1.81 & 3 \\
\hline 1202.33 & 14.5 & 12.48 & 2.02 & 3 \\
\hline 1202.35 & 15 & 12.76 & 2.24 & 3 \\
\hline 1202 & 8.41 & 8.41 & 0 & Overts \\
\hline
\end{tabular}

Table 7: Flow summery at the crossing - Culvert two for a 25 year returns periods, $13.00 \mathrm{~m}^{3} / \mathrm{s}$

\begin{tabular}{|l|l|l|l|l|}
\hline Col $(1)$ & Col $(2)$ & Col $(3)$ & Col $(5)$ & Col $(6)$ \\
\hline $\begin{array}{l}\text { Eeadwater } \\
\text { Elevation }(\mathrm{m})\end{array}$ & $\begin{array}{l}\text { Total } \\
\text { Discharge }\left(\mathrm{m}^{3} / \mathrm{s}\right)\end{array}$ & $\begin{array}{l}\text { Culvert } 1 \\
\text { Discharge }\left(\mathrm{m}^{3} / \mathrm{s}\right)\end{array}$ & $\begin{array}{l}\text { Roadway } \\
\text { Discharge }\left(\mathrm{m}^{3} / \mathrm{s}\right)\end{array}$ & Iteration \\
\hline 1207.27 & 0 & 0 & 0 & 1 \\
\hline 1207.68 & 1.5 & 1.5 & 0 & 1 \\
\hline 1207.91 & 3 & 3 & 0 & 1 \\
\hline 1208.11 & 4.5 & 4.5 & 0 & 1 \\
\hline 1208.29 & 6 & 6 & 0 & 1 \\
\hline 1208.45 & 7.5 & 7.5 & 0 & 1 \\
\hline 1208.61 & 9 & 9 & 0 & 1 \\
\hline 1208.75 & 10.5 & 10.5 & 0 & 1 \\
\hline 1208.89 & 12 & 12 & 0 & 1 \\
\hline 1208.98 & 13 & 13 & 0 & 1 \\
\hline 1209.15 & 15 & 15 & 0 & 1 \\
\hline $\mathbf{1 2 0 9 . 2 7}$ & $\mathbf{1 6 . 3 4}$ & $\mathbf{1 6 . 3 4}$ & $\mathbf{0}$ & Overtopping \\
\hline
\end{tabular}

Table 8: Flows summary at the crossing - Culvert two for a 50 year returns periods, $19.60 \mathrm{~m}^{3} / \mathrm{s}$

\begin{tabular}{|l|l|l|l|l|}
\hline Col $(1)$ & Col $(2)$ & Col $(3)$ & Col $(4)$ & Col $(5)$ \\
\hline $\begin{array}{l}\text { Headwater } \\
\text { Elevation }(\mathrm{m})\end{array}$ & $\begin{array}{l}\text { Total } \\
\text { Discharge }\left(\mathrm{m}^{3} / \mathrm{s}\right)\end{array}$ & $\begin{array}{l}\text { Culvert 1 } \\
\text { Discharge }\left(\mathrm{m}^{3} / \mathrm{s}\right)\end{array}$ & $\begin{array}{l}\text { Roadway } \\
\text { Discharge }\left(\mathrm{m}^{3} / \mathrm{s}\right)\end{array}$ & Iterations \\
\hline 1208.5 & 10 & 9.45 & 0.55 & 5 \\
\hline 1208.57 & 11 & 10.17 & 0.83 & 3 \\
\hline 1208.64 & 12 & 10.89 & 1.11 & 4 \\
\hline 1208.71 & 13 & 11.65 & 1.35 & 5 \\
\hline 1208.79 & 14 & 12.47 & 1.54 & 9 \\
\hline 1208.87 & 15 & 13.3 & 1.72 & 7 \\
\hline 1208.96 & 16 & 14.14 & 1.88 & 11 \\
\hline 1209.04 & 17 & 14.79 & 2.23 & 9 \\
\hline 1209.13 & 18 & 15.52 & 2.5 & 9 \\
\hline 1209.13 & 18.1 & 15.58 & 2.52 & 4 \\
\hline 1209.29 & 20 & 16.93 & 3.07 & 5 \\
\hline $\mathbf{1 2 0 8 . 2 7}$ & $\mathbf{7 . 2 1}$ & $\mathbf{7 . 2 1}$ & $\mathbf{0}$ & Overtopping \\
\hline
\end{tabular}

From the tables 5 - table 8 the result shows that there is flooding or overtopping from the culverts at each maximum floods which have a magnitude of greater than $8.41 \mathrm{~m}^{3} / \mathrm{s}$ for the culverts one at station sub-catchment $\operatorname{six}(\mathrm{S} . \mathrm{CM}-6)$ and $7.21 \mathrm{~m}^{3} / \mathrm{s}$ for the culvert two at station sub-catchment eight (S.CM-8). 
Table 9: Comparison of proposed design discharge and existed culverts capacity

\begin{tabular}{|c|c|c|c|c|c|c|}
\hline \multirow[b]{2}{*}{ Culverts Id } & \multicolumn{2}{|c|}{$\begin{array}{l}\text { Proposed Design } \\
\text { Discharge }\end{array}$} & \multicolumn{2}{|c|}{$\begin{array}{l}\text { Existed Culverts } \\
\text { Carrying Capacity }\end{array}$} & \multicolumn{2}{|c|}{$\begin{array}{l}\text { Difference Between } \\
\text { Proposed and Existed } \\
\text { Design Discharge }\end{array}$} \\
\hline & $\begin{array}{l}25 \text { year } \\
\text { design }\end{array}$ & $\begin{array}{l}50 \text { year } \\
\text { check }\end{array}$ & $\begin{array}{l}25 \text { year } \\
\text { design }\end{array}$ & $\begin{array}{l}50 \text { year } \\
\text { carrying }\end{array}$ & $\begin{array}{l}25 \text { year } \\
\text { design }\end{array}$ & $\begin{array}{l}50 \text { year } \\
\text { check }\end{array}$ \\
\hline culvert one @.S.CM -6 & 13.1 & 19.63 & 8.41 & 8.41 & 4.69 & 11.22 \\
\hline Culverts two@S.CM-8 & 10.50 & 18.1 & 4.32 & 4.32 & 3.29 & 13.78 \\
\hline
\end{tabular}

Depending on the observed difference between the proposed design discharge and the existed carrying capacity of the culverts the structure is hydraulically insufficient both for the design and check of proposed discharges. For culvert one the from the proposed design discharge, $35.8 \%$ for the 25 year return period and $57.1 \%$ for the 50 years check the flood flows out off the culvert and directly flows on the road and sometimes causes flooding the nearby community houses. For culvert two depending on the proposed design discharge, $31.1 \%$ for the 25 year return period and $76.13 \%$ for the 50 year return period for check this much flood flows out of the culverts.

\section{Conclusion}

After careful assessments of the effects of the poor drainage system on the road performance, the following main results had observed and described as below.

From personal observation of the site the drainage system of the town was highly used the rectangular open channel without covering the top part of the channels this leads the channel to filled with wastes, commercial residues, and the community itself use the channel as a means of the trade area. Those activate create reducing the size of the drainage structure and immediately it creates an overtopping of channels and flow on the roads also some portion of the drainage blocked with waste crates water stagnation for long period of times.

From hydraulic performance assessment of the existed drainage structures almost all the drainage systems design is hydraulically insufficient means that the proposed design discharge for both the design and check is much greater than the existed drainages structure working space (hydraulic capacity), this happens due to less involvement of professionals ( hydraulic engineer, hydrologist), future projection of the design structures was not considered the land use land cover change highly affects the peak discharge but not highly considered in the design stage, the communities awareness about the drainage structures was not good they did not consider the drainage system as a means of disposing stormwater rather they think of that as solid waste material disposal means.

Still, areas without drainage channels construction exist and the flow from those places create an overflow on the road and deteriorates the side of the roads highly this happens due to poor drainage alignment system with the roads.

From HY 8 culvert analysis the existed culverts have encountered an overtopping problem and the active working space of the culvert was insufficient to carry and bypass the coming proposed peak discharges.

\section{REFERENCES}

[1]. Belete, D. A. (2011). Road and urban storm water drainage network integration in Addis Ababa: Addis Ketema Sub-city. Journal of Engineering and Technology Research, Vol. 3(7), pp. 217-225.

[2]..AASHTO. (1991). American Association of State Highways and Transportation Officials Drainage Manual Hydraulics Report. Washington D.C.

[3]. AACRA. (2004). Addis Ababa City Road Authority Drainage Design Manual. Addis Ababa, Ethiopia.

[4]. Getachew KebedeWarati and Tamene Adugna Demissie. (2015). Assessment of the Effect of Urban Road Surface Drainage: A Case Study at GinjoGuduruKebele of Jimma Town. International Journal of Science, Technology and Society, Vol. 3, pppp. 164-173.

[5]. Derribew, M. Z. (2016). Socioeconomic Impacts of the 2006 Seasonal flooding alone prone Areas: the Case of Dire Dawa Town Administration, Ethiopia. International Journal of Sciences:Basic and Applied Research, 90-106, pp:90-106.

[6]. ERA. (2011). Ethiopia Road Authority Drainage design Manual. Addis Ababa.

[7]. ERA. (2013). Ethiopian Road Authority Drainage Design Mannual. Addis Ababa, Ethiopia.

[8].James D. Schall, P. L. (2012). Hydraulic Design of Highway Culverts Third Edition. U.S. Department Of Transportation.

[9].Mina, H. S. (2007). Road Maintenance of Drainage, Shoulders and Slopes. Journal of Indian Highways, $35-$ 38.

[10].Robbi Dribas (Mugenda, 1999). (2016). Causes and Effects of Poor Drainage System on the Asphalt Pavement Layer. Ethiopia.

[11].Zumrawi, Magdi M. E. (2014). The Impacts of Poor Drainage on Road Performance in Khartoum. International Journal of Multidisciplinary and Scientific Emerging Research, Vo.3, No.1, pp 901-90 